\title{
Concentration of Heavy Metals in Respirable Dust in Jos Metropolitan Area, Nigeria
}

\author{
Godwin M. Mafuyai, Ishaq S. Eneji*, Rufus Sha'Ato \\ Department of Chemistry, University of Agriculture, Makurdi, Nigeria \\ Email: ${ }^{*}$ eneji3@yahoo.com
}

Received 27 November 2013; revised 27 December 2013; accepted 5 January 2014

Copyright (C) 2014 by authors and Scientific Research Publishing Inc.

This work is licensed under the Creative Commons Attribution International License (CC BY). http://creativecommons.org/licenses/by/4.0/

(c) (i) Open Access

\begin{abstract}
The concentration of respirable dust at seven sampling stations in Jos metropolitan area, was measured weekly for three consecutive months (October 2012 to December 2012). Characterization of the dust particles shows that the concentration of fine dust $(<2.5 \mu \mathrm{m})$ ranged from 55.0 $124.9 \mu \mathrm{g} / \mathrm{m}^{3}$ while the coarse dust $(2.5-10 \mu \mathrm{m})$ varied from $20.0-124.4 \mu \mathrm{g} / \mathrm{m}^{3}$. FAAS analysis of the respirable dust shows that the concentrations of heavy metals ranged from $0.121-0.832$ $\mathrm{mg} / \mathrm{kg} \mathrm{Pb}, 0.019-0.111 \mathrm{mg} / \mathrm{kg} \mathrm{Cr}, 0.171-1.081 \mathrm{mg} / \mathrm{kg} \mathrm{Fe}, 0.002-0.056 \mathrm{mg} / \mathrm{kg} \mathrm{Mn}, 0.002-0.438$ $\mathrm{mg} / \mathrm{kg} \mathrm{Cd}, 0.696-1.712 \mathrm{mg} / \mathrm{kg} \mathrm{Zn,} 0.025-0.571 \mathrm{mg} / \mathrm{kg} \mathrm{Cu}$, and $0.021-0.478 \mathrm{mg} / \mathrm{kg} \mathrm{Ni}$, across the sites studied. The main sources of these heavy metals in the sampled area could be attributed to anthropogenic activities like open incineration of waste and vehicular traffic. The concentrations of $\mathrm{Cd}, \mathrm{Mn}$ and $\mathrm{Ni}$ were found to be far above the standard limits prescribed by the WHO for respirable dust. These results convey the health risk the inhabitants in the study area are exposed to. We therefore recommend that measures be taken to regulate these anthropogenic activities
\end{abstract}

\section{Keywords}

Mass; Concentration; Respirable Dust; Heavy Metals; Jos; Air Quality

\section{Introduction}

Pollution of the natural environment by heavy metals is a worldwide problem because these metals are indestructible and most of them have toxic effects on living organisms; while some of these elements are essential for humans, at high levels they can also pose toxicological risk [1]. About 4 - 8 percent of deaths occurring annually in the world are related to air pollution associated with anthropogenic activities [2]. Environmental sources for air pollutants could include crustal minerals, forest fires, construction and demolition activities,

${ }^{*}$ Corresponding author. 
mining and mineral processing, agricultural activities, sea spray, wind-blown dust, automobiles and other transportation related activities on the road [3]. The composition of the air pollutants can be inorganic, organic or complex mixtures of both. Among the many inorganic pollutants originating from anthropogenic activities, heavy metals are of a major concern due to their toxic and potential carcinogenic characteristics. In recent times, studies of air pollution especially in the urban environment have focused largely on respirable dust, including seasonal variation and the threat poses to human health [3]-[6].

Respirable dust pollution which contributes to atmospheric heavy metal load is derived through natural and anthro pogenic activities [7] [8]. The respirable fraction is composed of the very fine dust which is able to reach the lower bronchioles and alveolar regions of the lung, this dust has been implicated to have the potential to carry a high loading of contaminated species such as heavy metals and organic pollutants [9]. Respirable dust is a useful indicator of the level and distribution of heavy metals contamination in the atmosphere which may affect air quality with its deleterious environmental consequences, including harm to human life [10] [11]. It has been reported that metals absorbed in respirable dust suspended particulate produces tissue damage of the lungs [12]. The health effects of toxic metals in the air and from road deposited dust on human is better appreciated if one consider the fact that an active person typically inhales 10,000 to 20,000 litres of air daily [13]. It is logical to note that, this intake increases with vigorous exercise. During inhalation, these pollutants may enter the numerous tiny air sacs deep inside the lungs and also blood stream thereby affecting several other organs than the lungs [13]. It has been estimated that a man can live weeks without food and five days without water, but only five minutes without air [14]. This implies that air is very essential for human existence. In view of the increasing evidences of respirable dust on human health and environment, not much data on respirable dust, one of the major pre-requisite for health studies is available for urban areas in Nigeria. Information regarding respirable dust quality in Jos metropolis which is currently experiencing road construction infrastructure and high inflow of vehicular traffic, is not available. This study represents a unique combination of sampling respirable dust and its characterization. Also, it evaluates the levels of some selected heavy metals ( $\mathrm{Pb}, \mathrm{Cr}, \mathrm{Fe}, \mathrm{Mn}, \mathrm{Cd}, \mathrm{Zn}, \mathrm{Cu}$ and $\mathrm{Ni}$ ) in respirable dust of Jos metropolis, Nigeria. The study will form a baseline that can be used for planning/management strategies to achieve better environmental quality and sustainable development in the Jos metropolitan area.

\section{Materials and Method}

\subsection{Study Area}

Jos is one of the most densely populated areas in Plateau State, Nigeria (900,000 inhabitants based on the 2006 population census estimate). Jos City (latitude $9^{\circ} 56^{\prime}$ North and longitude $8^{\circ} 53^{\prime}$ East) is at an elevation of about 1238 metres above sea level and hosts many industrial sites for steel, brewery, textile, smelting etc. It also includes power plant and experiences some of the state heaviest road traffic. It enjoys a more temperate climate than much of the rest of Nigeria. The State is characterized landscape of undulating highlands and peaks like the famous Shere Hill over 4829 meters above sea level.

\subsection{Sampling}

A respirable dust sampler (AAS 217BL) was placed on an elevated platform of $1.5 \mathrm{~m}$ high at a distance of $20 \mathrm{~m}$ away from obstructions and used to sample the dust from Anglo Jos (AJ), Terminus Roundabout (TR), FarinGada (FG), Polo Roundabout (PR), Secretariat Junction (SJ), Hill Station Junction (HS) and Bukuru Low Cost Housing Estate (BL) (Figure 1). After setting the machine, marked weighed sampling bottles were fixed under the conical hopper one at a time. Marked and pre-weighted filter paper was then clamped between the top cover of filter adaptor assembling of the machine. The filter cover was then closed and the machine switched on taking note of the time. The filter papers and sample bottles were removed after 8 hours and reweighed to obtain their weight after exposure. The volume of sampled air was obtained from flow-meter readings and sampling time. Calculations were carried out using standard methods of National Environmental Engineering research Institute's. The concentrations of the fine-and coarse-dusts obtained using the following mathematical expression:

$$
R D_{f} \mu \mathrm{g} / \mathrm{m}^{3}=\left\{\left(M_{2}-M_{1}\right) / V\right\} \times 10^{6}
$$

where:

$R D_{f}$ is the mass concentration of dust in $\mu \mathrm{g} / \mathrm{m}^{3}$, 


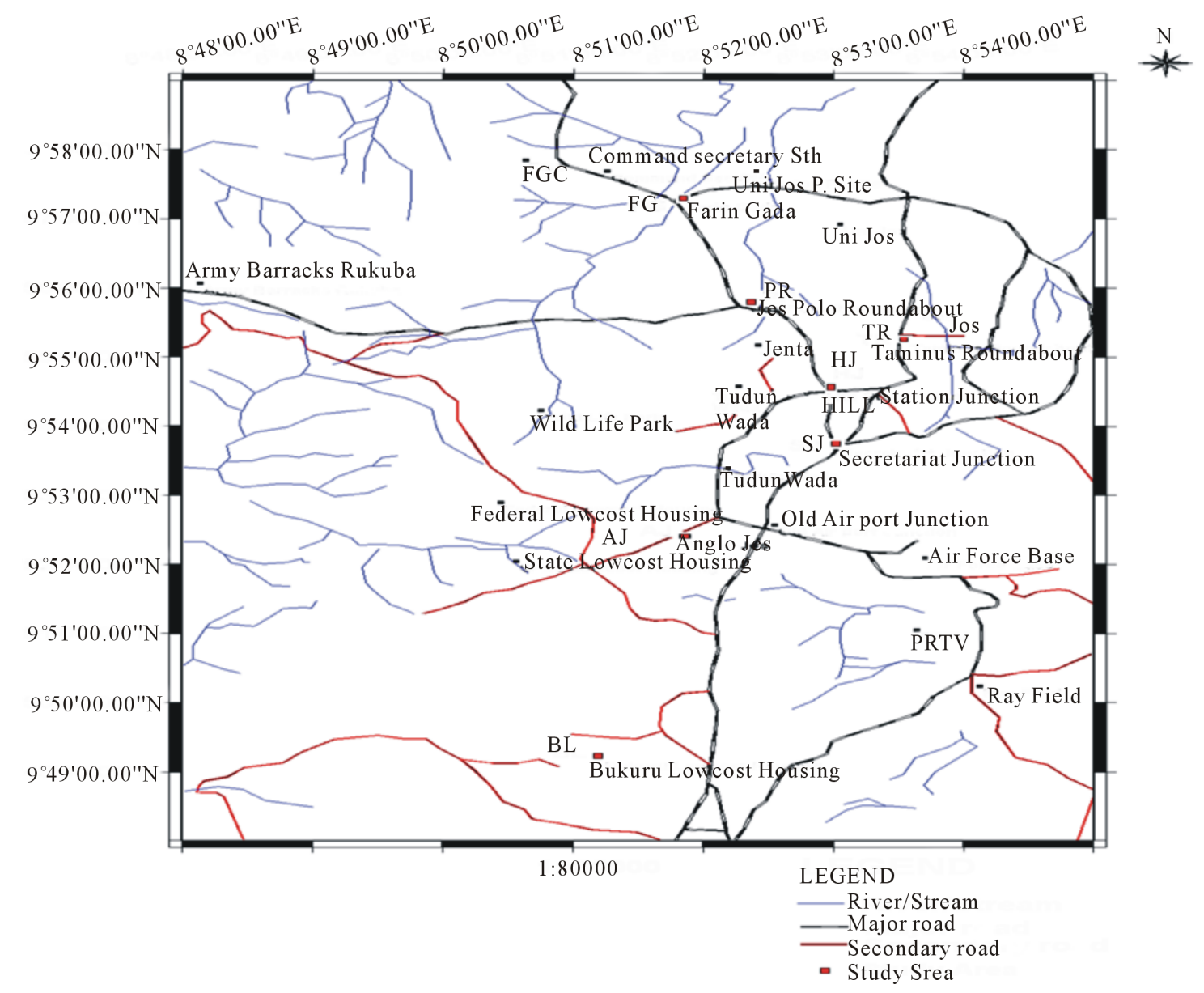

Figure 1. Map of Jos indicating the study areas.

$M_{1}$ and $M_{2}$ were for the initial and final mass of filter paper in grams, respectively.

$10^{6}$ was conversion factor from grams to micrograms.

$V$ represent the volume of sampled air in $\mathrm{m}^{3}$ which is calculated as $V=\phi T$,

$\phi$ is average air flow rate in $\mathrm{m}^{3} / \mathrm{min}$ and

$T$ is sampling time, in minutes.

The respirable dust sample collected on filter paper was stored in desiccators and removed as needed and digested in concentrated nitric acid. After the digestion the content was filtered through Whatman filter paper number 42 and final volume made up to $100 \mathrm{~mL}$ with deionised water. A blank was also prepared in similar way as the sample. The filtrate was examined for the concentration of Fe, $\mathrm{Zn}, \mathrm{Cu}, \mathrm{Pb}, \mathrm{Mn}, \mathrm{Ni}$, Cd and $\mathrm{Cr}$ using AAS (PG 990) in accordance with the user manual.

\section{Results and Discussion}

The experimental data collected in this research were analyzed statistically using bar charts. The six sampling sites were carefully selected due to various human activities such as industrial site, construction works and heavy traffic congested area while one other site Bukuru Low-Cost Housing Estate (BL), a residential area, was selected as a control. The mean values of the mass of dusts in each sampling stations along with their standard deviations are presented in Table 1.

The total mass of fine dust $(<2.5 \mu \mathrm{m})$ collected in Secretariat Junction (SJ) and Farin Gada (FG) were highest (0.193 g) while the least was found at Polo Roundabout (PR) (0.102 g). The masses were expectedly higher along high traffic roads and construction sites than areas with low traffic. This high value of respirable dusts may have a negative impact on the inhabitants thereby causing respiratory problems in these areas [7]. Tsor [15] 
reported high value of total masses of the dust collected from Jos to be $3.3 \pm 1.1 \mathrm{~g}$ during the harmattan using smeared microscope slide for sample collections. This high value could be due to climatic condition of harmat$\tan$ as it is similar to haze where at time visibility is very poor. In addition to harmattan situation, the methods of sampling could also contribute to the high masses.

In this research, the mass of fine dust particles were higher than the coarse dust in most of the sampling sites, except Terminus Roundabout (TR) and Farin-Gada (FG). This observation was in line with literature report that, naturally derived heavy metals are usually found in coarse particles [16]. However, heavy metals of anthropogenic origin are mainly distributed in fine particles which are able to carry more toxic chemicals to human being and ecosystem than coarse fractions [17]. The mean concentrations obtained for fine dust and coarse dust for all the sampling stations are graphically presented in Figures 2 and 3, respectively.

The results shows that the fine dust concentration in Secretariat Junction $\left(124.9 \mu \mathrm{g} / \mathrm{m}^{3}\right)$ and Coarse dust (2.5 -

Table 1. Respirable dust mass, flow rate and volume of air sampled in Jos metropolis from October to December, 2012.

\begin{tabular}{|c|c|c|c|c|c|c|}
\hline $\begin{array}{l}\text { Sample } \\
\text { Codes }\end{array}$ & $\begin{array}{l}\text { Mean Mass of } \\
\text { Fine Dust (g) }\end{array}$ & $\begin{array}{l}\text { Mean Mass of } \\
\text { Coarse Dust (g) }\end{array}$ & $\begin{array}{c}\text { Flow Rate } \\
\left(\mathrm{m}^{3} / \mathrm{min}\right)\end{array}$ & $\begin{array}{c}\text { Average Sampling } \\
\text { Time (mins) }\end{array}$ & $\begin{array}{l}\text { Volume of Air } \\
\text { Sampled }\left(\mathrm{m}^{3}\right)\end{array}$ & $\begin{array}{l}\text { Total Dusts } \\
\text { (g) }\end{array}$ \\
\hline $\mathrm{AJ}$ & $0.095 \pm 0.005$ & $0.083 \pm 0.007$ & 0.77 & 1440 & 1109 & 0.178 \\
\hline $\mathrm{TR}$ & $0.091 \pm 0.006$ & $0.069 \pm 0.006$ & 0.70 & 1440 & 1013 & 0.170 \\
\hline $\mathrm{FG}$ & $0.069 \pm 0.005$ & $0.124 \pm 0.005$ & 0.69 & 1440 & 989 & 0.193 \\
\hline PR & $0.077 \pm 0.002$ & $0.025 \pm 0.002$ & 0.68 & 1440 & 982 & 0.102 \\
\hline SJ & $0.125 \pm 0.004$ & $0.068 \pm 0.005$ & 0.70 & 1440 & 1001 & 0.193 \\
\hline HS & $0.086 \pm 0.002$ & $0.051 \pm 0.003$ & 0.75 & 1440 & 1081 & 0.137 \\
\hline $\mathrm{BL}$ & $0.072 \pm 0.002$ & $0.027 \pm 0.010$ & 1.90 & 1440 & 1289 & 0.099 \\
\hline
\end{tabular}

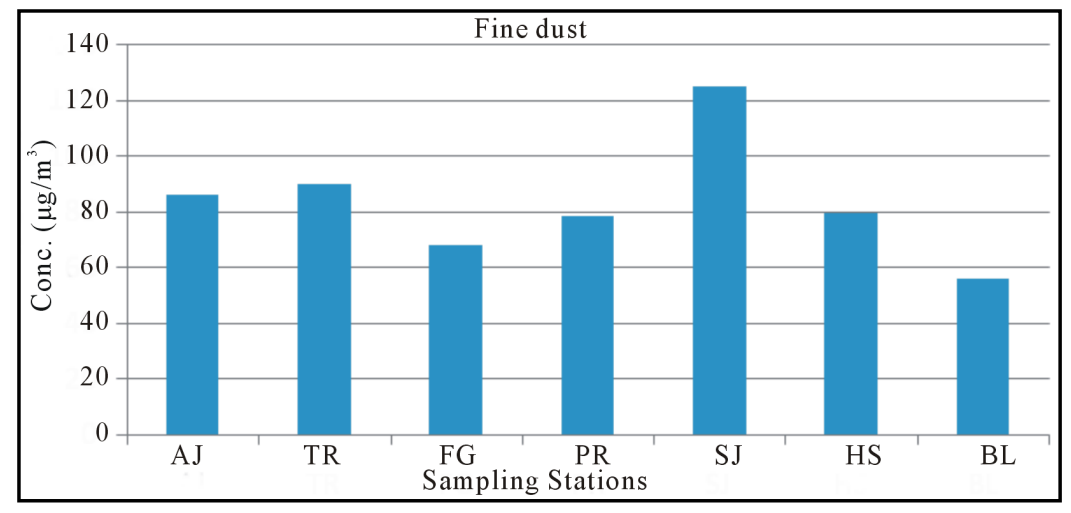

Figure 2. Mean concentration of fine dust in Jos metropolitan area.

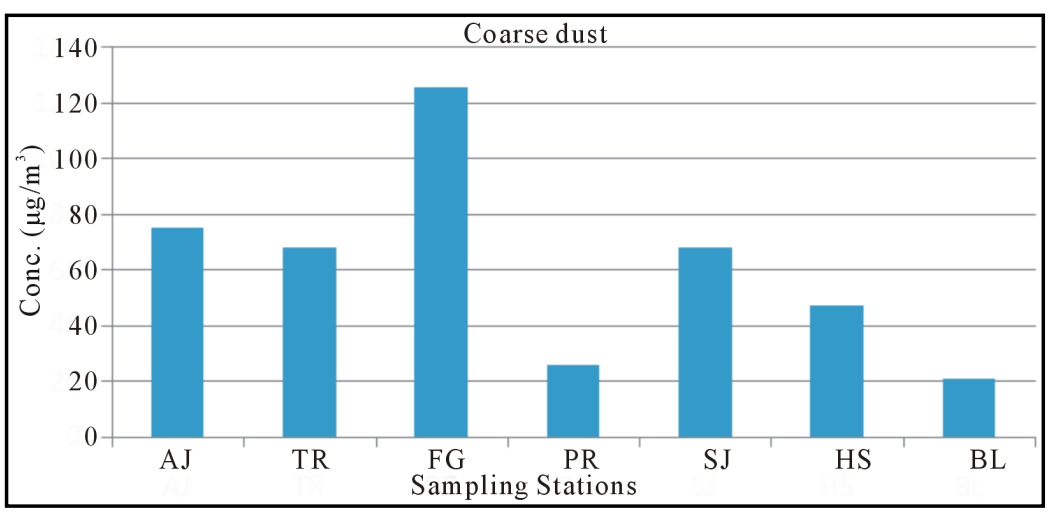

Figure 3. Mean concentration of coarse dust in Jos metropolitan area. 
$10 \mu \mathrm{m})$ at Farin Gada $\left(125.4 \mu \mathrm{g} / \mathrm{m}^{3}\right)$ were above WHO standards. This may be as result of high vehicular traffic that might be responsible for the high concentration of respirable dust in these areas. The mean concentration $\left(112.57 \mu \mathrm{g} / \mathrm{m}^{3}\right)$ of the dusts (that is, fine-and coarse—dust) in Jos metropolitan area of Plateau State is lower compared to literature value of $739.69 \mu \mathrm{g} / \mathrm{m}^{3}$ obtained at Otukpo in Benue State [18]. This could be attributed to differences in the nature of roads (that is tarred or not) in the two areas and the type of fuel used, by vehicles.

There have been also reports on the adverse health effects, even when respirable dust concentrations are below Ambient Standards of EPA or WHO [19]. It is logical to note that, these standards ignored the synergistic effects of concentration of toxic air pollutants [20]. Respirable dust in three sub-urban and rural sites has also been reported to vary from $37-959 \mu \mathrm{g} / \mathrm{m}^{3}$ and $151-422 \mu \mathrm{g} / \mathrm{m}^{3}$ at sub-urban site at Ronkee, India [21]. The mean concentration $\left(112.57 \mu \mathrm{g} / \mathrm{m}^{3}\right)$ of respirable dust reported in this work is within the range of literature values reported by various workers.

\section{Heavy Metals}

The concentration of eight (8) heavy metals ( $\mathrm{Pb}, \mathrm{Cr}, \mathrm{Fe}, \mathrm{Mn}, \mathrm{Cd}, \mathrm{Cu}, \mathrm{Ni}$ and $\mathrm{Zn}$ ) at each sampling station was determined by flame atomic absorption spectrometry (FAAS). The results for the seven sampling sites (plus control) in Jos metropolis from October-December, 2012 are presented in Figures 4-11. These results show that our analytical procedure and method of detection provided data within an acceptable range of literature values.

$\mathrm{Pb}$ naturally occurred as a bluish-grey metal found in small amounts in the earth's crust. When $\mathrm{Pb}$ is released to the air from industry or burning of fossil fuels or waste, it stays in air about 10 days and fall as particles in to

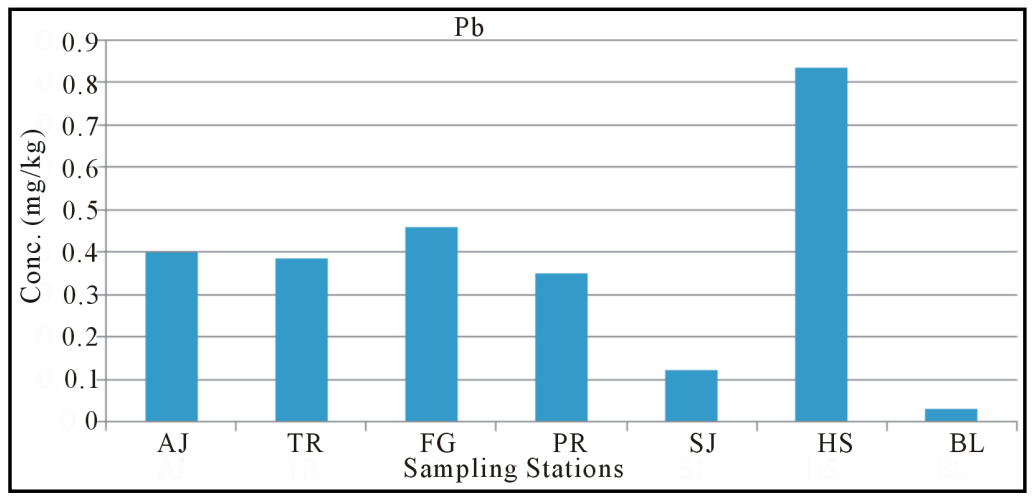

Figure 4. Concentration of $\mathrm{Pb}$ in respirable dust in Jos metropolitan area.

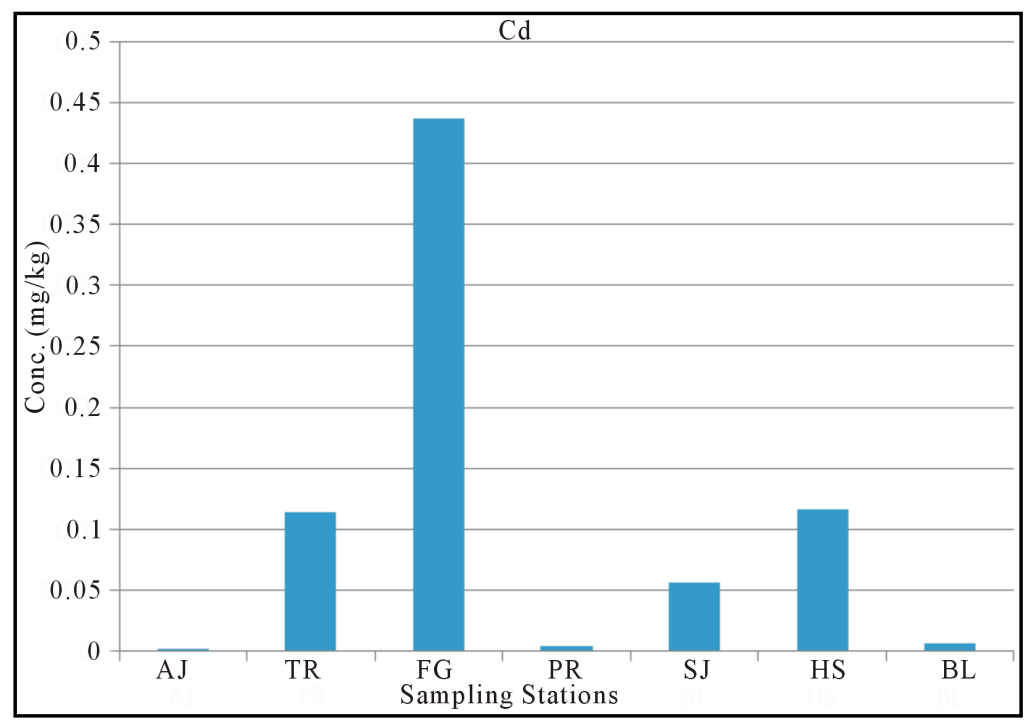

Figure 5. Concentration of Cd in respirable dust in Jos metropolitan area. 


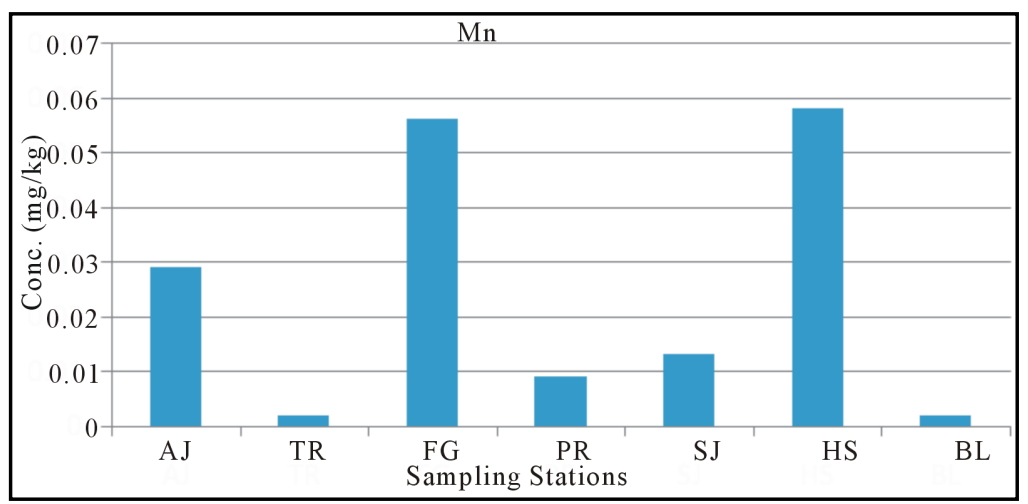

Figure 6. Concentration of $\mathrm{Mn}$ in respirable dust in Jos metropolitan area.

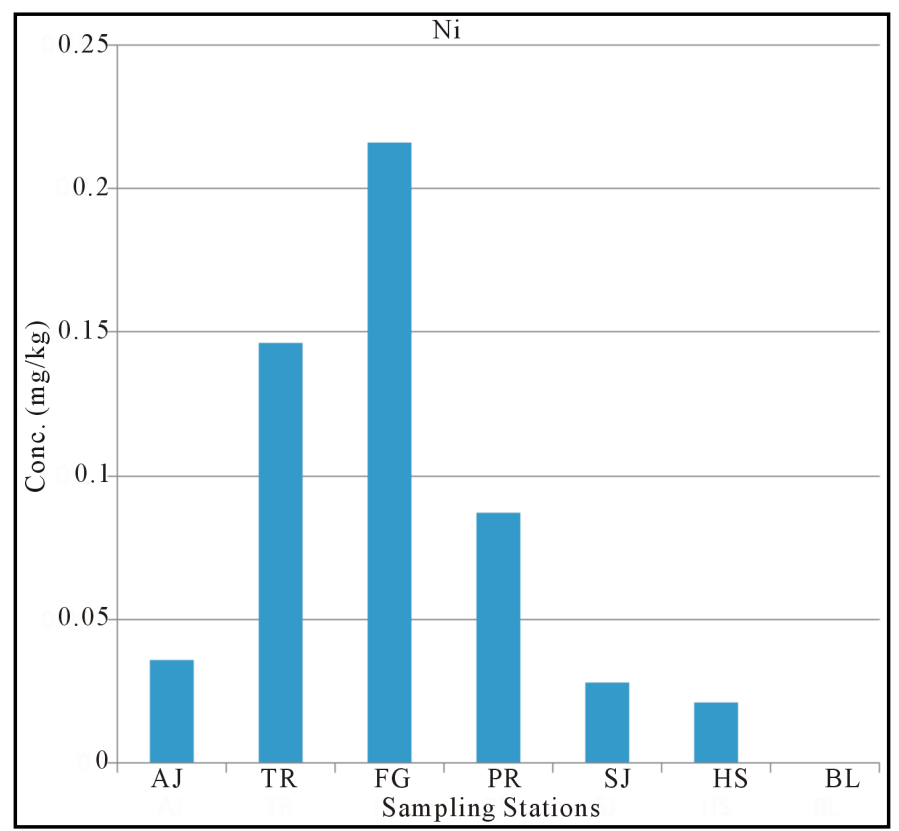

Figure 7. Concentration of $\mathrm{Ni}$ in respirable dust in Jos metropolitan area.

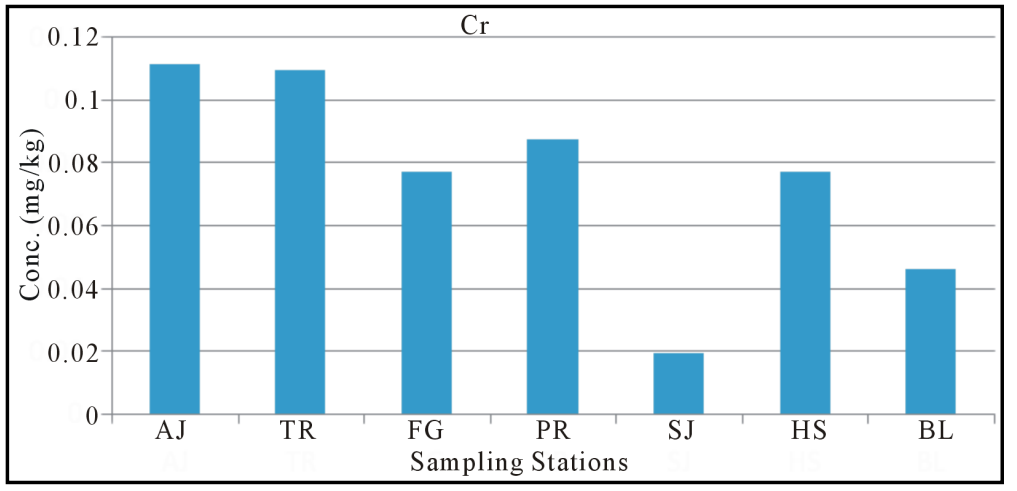

Figure 8. Concentration of $\mathrm{Cr}$ in respirable dust in Jos metropolitan area.

the soil out of the air. $\mathrm{Pb}$ dust, fumes or vapours are more easily absorbed from the respiratory tract. The concentration of $\mathrm{Pb}$ determined in all the sampling sites ranges from $0.121-0.832 \mathrm{mg} / \mathrm{kg}$ during the period of 


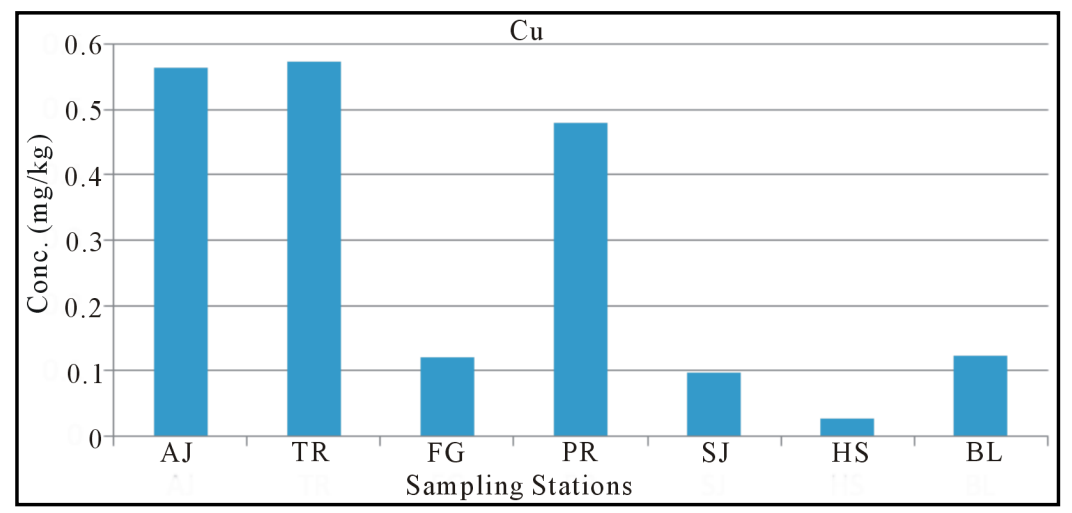

Figure 9. Concentration of $\mathrm{Cu}$ in respirable dust in Jos metropolitan area.

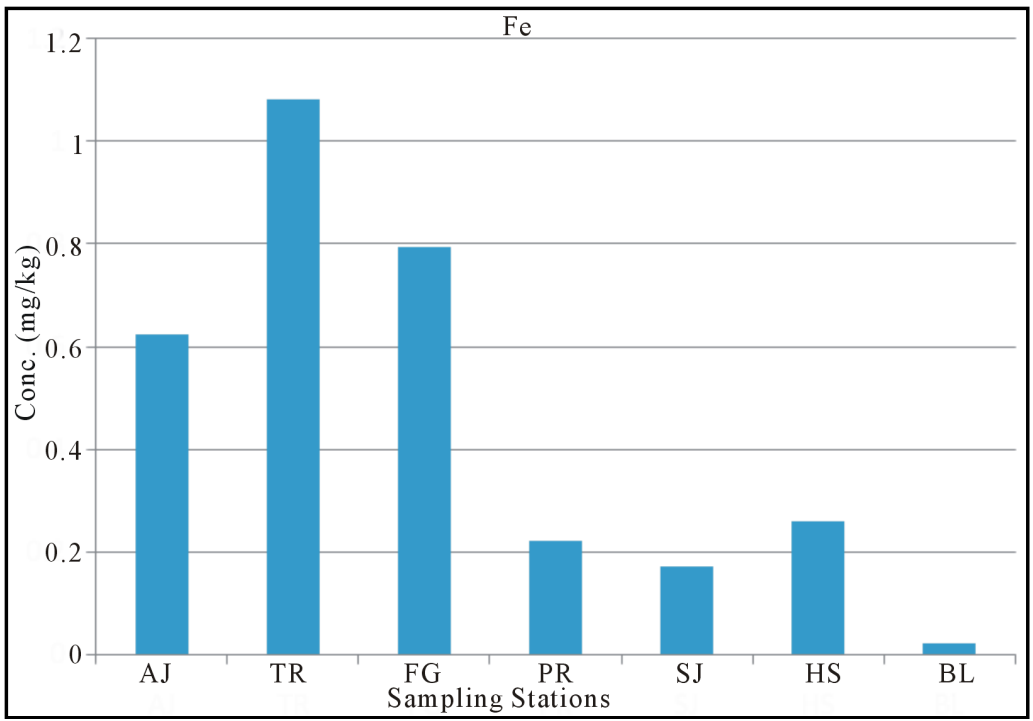

Figure 10. Concentration of Fe in respirable dust in Jos metropolitan area.

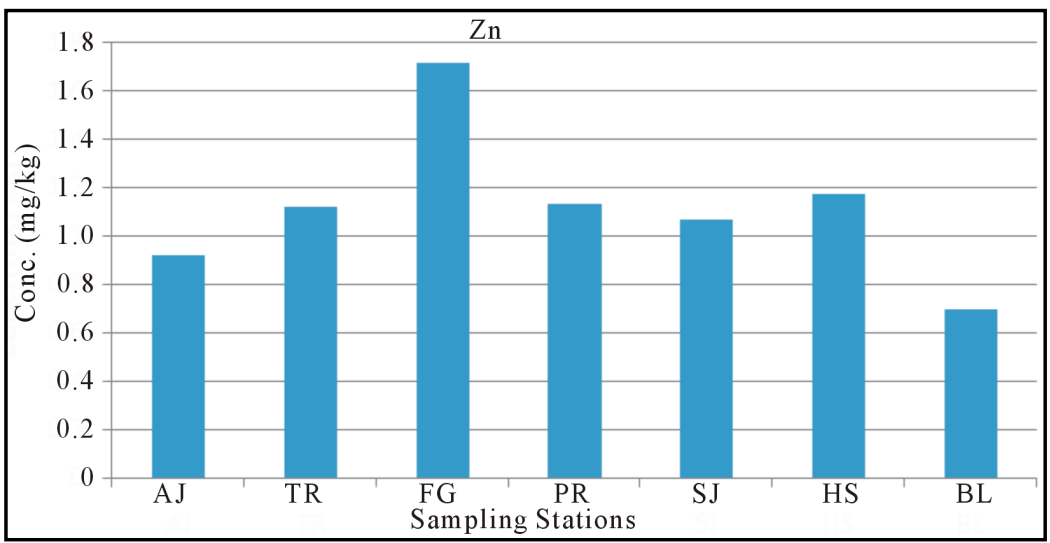

Figure 11. Concentration of $\mathrm{Zn}$ in respirable dust in Jos metropolitan area.

assessment as depicted in Figure 4. This was found to exceed the annual average $\mathrm{Pb}$ limit value of $0.5 \mathrm{mg} / \mathrm{m}^{3}$ [22]. This may be associated with manufacturing of automobile batteries, pigments and cable sheathing. Also usage of $\mathrm{Pb}$ in plumbing, solders, paints, ceramic-ware, plastics and ammunition pose a significant environmental risk [5]. It might be due to wind-blown from mechanical workshops, oil leakages from cars and vehicular ex- 
haust at the sites [23]. Once absorbed through the acute respiratory tract it is distributed particularly to the liver and kidney, and is then stored in the bones. $\mathrm{Pb}$ affects the red blood cells and cause damage to internal organs, as well as causes effects to the immune system. Exposure to $\mathrm{Pb}$ is more dangerous young and unborn children because it leads to premature births, smaller babies, and decreased metal ability in the infant, learning difficulties, and reduced growth in young children.

$\mathrm{Cd}$ is found as a mineral combined with elements such as oxygen $(\mathrm{CdO})$, chlorine $\left(\mathrm{CdCl}_{2}\right)$ or sulphur $\left(\mathrm{CdSO}_{4}\right.$ or CdS). It enters air from mining, industry, and burning coal and household wastes. Particles of Cd in air can travel long distances before falling to the ground or water. The concentration of $\mathrm{Cd}$ in all the areas was higher than the standard limit value of $0.005 \mathrm{mg} / \mathrm{kg}$ as our result ranges from $0.02-0.437 \mathrm{mg} / \mathrm{kg}$. The highest value was obtained at Farin-Gada while the least value was obtained at Anglo Jos (Figure 5). The high Cd in some sampling area may be associated with industrial emissions especially steel production units because a large amount of Cd plated steel scrap is recycled in these industries. Other possible source include burning of municipal wastes containing discarded Ni-Cd batteries and plastics containing Cd pigments; vehicular emissions including tyre abrasions and cigarette smoking [5]. Cd stays in the body for a very long time and hence, exposure to lower levels of $\mathrm{Cd}$ leads to a build up of $\mathrm{Cd}$ in the kidneys and may lead to kidney disease. Other potential long term effects are lung damage, fragile bones and abdominal pain [6].

Although, $\mathrm{Mn}$ is an essential nutrient element for both plants and animals but very high concentration in the respirable dust could be dangerous. The concentration of Mn determined in all the sites ranges from 0.002 $0.058 \mathrm{mg} / \mathrm{kg}$ during the period of assessment. The highest concentration of Mn was obtained at Hill Station Junction, while the least value obtained at Terminus Roundabout (see Figure 6). Although, the values obtained were lower than the WHO and EU limit value of $0.15 \mathrm{mg} / \mathrm{kg}$. This may be as a result of anthropogenic activities around the sites that result in high temperature combustion of manganese rich-fuel enhancers or smelting from incineration and coal fire.

$\mathrm{Ni}$ is found primarily combined with oxygen or sulphur and small particles in the air settle to the ground or are taken out of the air in rain. The concentration of Ni determined in all the sites ranges from $0.021-0.216$ $\mathrm{mg} / \mathrm{kg}$. The concentration of Ni at Bukuru Low Cost Estate (control site) was not detected perhaps due to very low concentration beyond the detection limit as shown in Figure 7. The observed concentration of Ni in other sampling sites may be as a result of anthropogenic sources of nickel emissions to the atmosphere through combustion of fuel and residual oil burning, mining, and municipal waste incineration. Also local sources such as heating, heavy traffic and industry in a particular area are most likely sources. Other sources of exposure are tobacco smoke, auto exhaust, fertilizers, food processing, hydrogenated-fats-oils and industrial waste. The most common adverse health effect of $\mathrm{Ni}$ in humans is an allergic reaction such as skin rash. Cancers of the lung and nasal sinus have resulted when workers breathed dust containing high levels of nickel compounds while working in nickel processing plants [6].

In nature $\mathrm{Cr}$ is part of ores mainly as chromite $\left(\mathrm{FeCr}_{2} \mathrm{O}_{4}\right)$ and cryolite $\left(\mathrm{PbCrO}_{4}\right)$ and is essential for the insulin molecule to bring glucose into the cells for glycolysis. The $\mathrm{Cr}$ particles in air settle in less than ten (10) days and sticks strongly to soil particles while in water it sticks to dirt particles that fall to the bottom and only a small amount dissolves. The concentration of $\mathrm{Cr}$ determined in respirable dust in all the sites ranges from 0.019 $0.111 \mathrm{mg} / \mathrm{kg}$ during the period of assessment. The highest value was obtained at Anglo Jos (AJ) while the least value was obtained at Secretariat Junction (SJ) as depicted in Figure 8 below. Heavy metal pollution of air can arise from many sources, but $\mathrm{Cr}$ arises commonly from fossil fuel burning, preparation of nuclear fuels, electroplating such as chrome-steel or chrome-nickel (stainless steel) and other alloys, brick in furnaces, and dye and pigment [3] [6]. All forms of $\mathrm{Cr}$ can be toxic at high levels but $\mathrm{Cr}^{6+}$ is more toxic than $\mathrm{Cr}^{3+}$. Exposure to $\mathrm{Cr}^{6+}$ in air can damage and irritate your nose, lungs, stomach and intestines. Skin contact with solids containing $\mathrm{Cr}^{6+}$ may lead to ulcers.

Although, $\mathrm{Cu}$ is an essential substance to human life, but in high doses it cause anemia, liver and kidney damage, stomach and intestinal irritation. The concentration of $\mathrm{Cu}$ determined in all the sampling sites ranges from $0.025-0.571 \mathrm{mg} / \mathrm{kg}$. The concentrations of Cu were very high at Anglo Jos (AJ), Terminus Roundabout (TR) and Polo Roundabout (PR) sampling sites as depicted in Figure 9. The consistent occurrence of Cu implies that the particulates originate from weathering of a unique form of a local geological material due to wind erosion, construction work, traffic related and residential activities.

The concentration of Fe determined in all the sites ranges from $0.171-1.081 \mathrm{mg} / \mathrm{kg}$. The highest concentration of Fe was obtained at Terminus Roundabout (TR), while the least value was obtained at Secretariat Junction 
(SJ) (see Figure 10). Generally, concentration of Fe was ranked second highest after Zn concentration in the respirable dust across the sampling sites. The consistent high occurrences of Fe imply that the particulates originate from weathering of a unique form of local geological materials due to wind erosion, construction work, traffic related and residential activities.

$\mathrm{Zn}$ is one of the commonest elements in the earth's crust and is found in air, soil, water, and is also present in all foods. It attaches to dust particles in the air and rain removes Zn dust particles from air into the soil and water. $\mathrm{Zn}$ is an essential element in our diet, insufficient amount of it can cause health problems and too much of it is also harmful. The concentration of Zn determined in all the sites ranges from $0.915-1.712 \mathrm{mg} / \mathrm{kg}$. Similarly, the highest Zn concentration was obtained at Farin-Gada (FG), while the least value was obtained at Anglo Jos as presented in Figure 11. The presence of $\mathrm{Zn}$ in the atmosphere could be attributed to wind-blown soil road dust, metallurgical plants and brass/zinc production facilities [5]. The consistent occurrences of $\mathrm{Zn}$ imply that the particulates originate from weathering of a unique form of local geological materials due to wind erosion, construction work, traffic related and residential activities. Breathing large amounts of $\mathrm{Zn}$ as dust or fumes can cause $\mathrm{s}$ specific short-term disease called metal fume fever. This is believed to be an immune response affecting the lungs and body temperature.

\section{Conclusion}

Generally, mass of fine-and coarse — dust were higher along high traffic roads and construction sites than areas with low traffic. The result of analysis showed that the average $\mathrm{Fe}, \mathrm{Zn}, \mathrm{Cu}$, and $\mathrm{Cr}$ concentrations determined at Anglu Jos, Terminus roundabout, Farin-Gada, Polo Roundabout, Secretariat Junction, Hill Station Junction and Bukuru Low Cost Housing Estate sites over the period of the study were below the WHO and EU standards. However, the reverse was the case for $\mathrm{Pb}, \mathrm{Mn}, \mathrm{Cd}$ and $\mathrm{Ni}$ as their values were extremely higher than the standard. Although the concentration of metals in other sites was generally low, the cumulative effect may be significant considering the presence of heavy metals in the environment. The data obtained for the study demonstrated that the distribution of metal concentration in the study area has come about as a result of anthropogenic influences and vehicular emissions.

\section{Acknowledgements}

We would like to thank the University of Jos, Nigeria for the financial support for this research. Also, our appreciation goes to Mr. Daret Plangnan of Geology Mining Department, Jos for allowing us to use their AAS for heavy metals determination.

\section{References}

[1] Shinggu, D.Y., Ogugbuaja, V., Toma, O. and Barminas, J.T. (2010) Determination of Heavy Metals in Street Dust in Yola, Nigeria. African Journal of Pure and Applied Chemistry, 4, 17-20.

[2] Lopez, J.M., Callen, M.S., Murillo, R., Garcia, T., Navarro, M.V., de la Cruz, M.T. and Mastral, A.M. (2005) Levels of Selected Metals in Ambient Air PM10 in an Urban Site of Zaragoza, Spain. Environmental Research, 99, 58-67.

[3] Melaku, S., Morris, V., Raghavan, D. and Hosten, C. (2008) Seasonal Variation of Heavy Metals in Ambient Air and Precipitation, at a Single Site in Washington, DC. Environmental Pollution, 155, 88-98.

[4] Bhargava, A., Gupta, K., Bhargava, R. and Pardhi, S. (2003) The Effects Automobile Exhaust on Total N, P and Heavy Metals of Road Side Sugarcane at District, Saharanpur. Ad Plant Science, 16, 557-560.

[5] Awan, M.A. and Ahmed, S.H. (2011) Determination of Total Suspended Particulate Matter and Heavy Metals in Ambient Air of Four Cities of Pakistan. Ironical Journal of Energy \& Environment, 2, 128-132.

[6] Lazor, P., Tomas, J., Toth, T., Toth, J. and Ceryova, S. (2012) Monitoring of Air Pollution and Atmospheric Deposition of Heavy Metals by Analysis of Honey. Journal of Microbiology, Biotechnology and Food Sciences, 1, 522-533.

[7] Kim, K., Lee, J. and Jang, M. (2002) Metals in Airborne Particulate Matter from the First and Second Industrial Complex Area of Taejon City, Korea. Environmental Pollution, 118, 41-51.

[8] Shah, J., Nagpa, J.T. and Brnadon, C. (2006) Urban air Quality Management Strategy in Asia-Guide Book. The World Bank, USA, 17-21.

[9] Ahmed, F. and Ishiga, H. (2006) Trace Metals Concentration in Street Dusts of Dhaka City Bangladesh. Atmospheric Environment, 40, 3835-3844. 
[10] Sezgin, N., Ozean, H.K., Demir, G., Nemlioglu, S. and Bayet, C. (2006) Determination of Heavy Metals in Street Dust in Istanbul Highway. Environmental International, 29, 797-985.

[11] Aybek, A. and Selcuk, A. (2007) Dust Exposures in Tractor and Combine Operations in Eastern Mediterranean, Turkey. Journal of Environmental Biology, 28, 717-722. http://www.jeb.co.in/

[12] Pope, C.A., Bates, D.A. and Raizenne, M.E. (1995) Health Effects of Particulate Air Pollution: Time for Reassessment? Environmental Health Perspective, 103, 472-479.

[13] Gbadebo, A.M. and Bankole, O.D. (2007) Analysis of Potententially Toxic Metals in Airborne Cement Dust around Sagamu South Western Nigeria. Journal of Applied Sciences, 7, 35-40.

[14] Rao, M.N. and Rao, H.V.N. (1989) Air Pollution. Data McGraw-Hill Publishing Company Ltd., New Delhi, 10-25.

[15] Tsor, O.J. (2003) The Characterization of Atmospheric Aerosol during Harmattan in Three Nigerian Cities. M.Sc. Thesis, University of Jos, Jos.

[16] Stone, E.A., Yoon, S.C. and Schauer, J.J. (2011) Chemical Characterization of Fine and Coarse Particles in Gosan, Korea during Springtime Dust Events. Aerosol Air Quality Research, 11, 31-43.

[17] Zhao, J., Zhang, F., Xu, Y., Chen, J., Yin, L., Shang, X. and Xu, L. (2011) Chemical Characterizations of Particulate Matter during a Heavy Dust Episode in a Coastal City, Xiamen. Aerosol Air Quality Research, 11, 299-308.

[18] Sombo, T. (2006) Thesis Particulate Matter Sampling and Characterization. M.Sc. Thesis, University of Agriculture, Makurdi.

[19] Peters, A., Dockery, D.W., Millerm J.F. and Mittelman, M.A. (2001) Increase Particulate Matter and the Triggering Myocardial Infarction. Circulation, 103, 2810-2815.

[20] Curtis, L., Pea, W., Smith-Willis, P., Fenyves, E. and Pan, Y. (2006) Adverse Health Effects of Outdoor Air Pollutants. Environment International, 32, 815-830.

[21] Vandana, T., Gurjar, B.R., Joshi, N. and Kumar, P. (2011) PM10 and Heavy Metals in Suburban and Rural Atmospheric Environments of Northern India. Department of Civil Engineering, Indian Institute of Technology Roorkee, Roorkee.

[22] National Environmental Protection Council (NEPC) (2002) Ambient Air Quality Standards. http://www.environment.gov.au/atmosphere/airquality/standards.html

[23] USEPA (2012) Air Quality Criteria for Particulate Matter. Vol. 1-3, Office of Research and Development, Washington DC (EPA Report No.EPA/001a-c). 